NEWS

\title{
Migration threatens to send flu south
}

\section{Researchers fear that the bird flu virus's next stop will be Africa, where dependence on poultry means that} the consequences could be even worse than in southeast Asia. Tom Simonite reports.

The deadly H5N1 bird flu virus is expected to be carried by birds into the Middle East and east Africa within weeks, the United Nations' Food and Agriculture Organization (FAO) warned last week.

Concern is growing that the Rift Valley in east Africa is particularly at risk. Researchers told Nature that if the virus reaches the area's lakes, the health and economic consequences could be even worse than in southeast Asia, where the virus is endemic in many regions.

${ }^{\alpha}$ The next step we expect the virus to take is into Africa, because that is on the main migratory route for birds," says Ward Hagemeijer of conservation organization Wetlands International in Wageningen, the Netherlands. "The first birds are alreadyin east Africa." There is no definitive evidence that migratory birds are carrying the disease, he says, but the pattern of the virus's spread points strongly to wildfowl travelling southwest from northern Russia to east Africa (see 'Ornithologists on the front line').

Outbreaks have already occurred along the route in Romania and Turkey, where they seem to have been controlled by culls and quarantine orders. But the migration is now in full swing, and some birds have crossed the Middle East and reached the Rift Valley. Middle Eastern states have stepped up efforts to plan for possible outbreaks, and some are monitoring migrating birds, but there has been little response in more vulnerable east African countries. This means that if the virus arrives there, it could quickly become endemic.

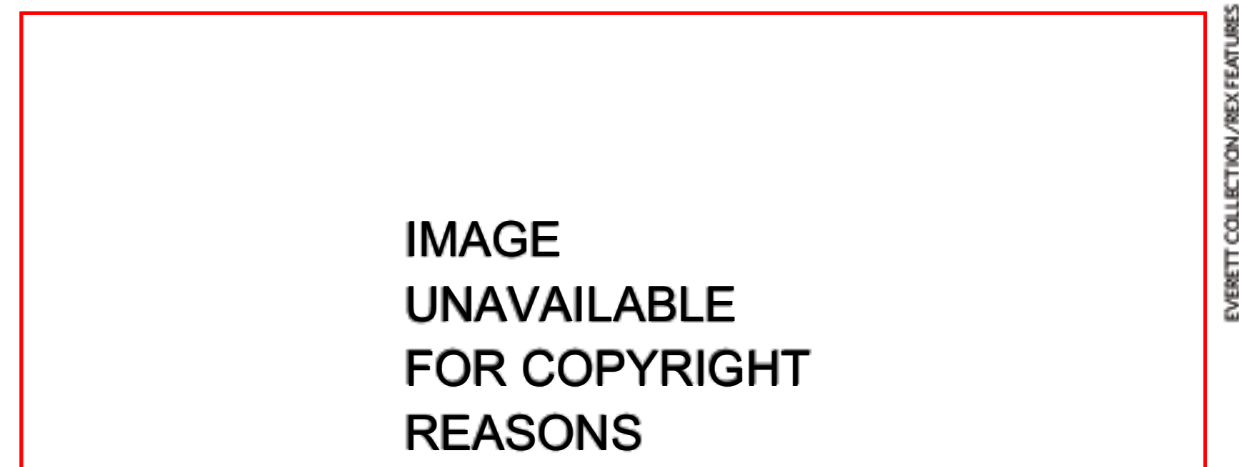

Migratory birds couldexpand the geographical spread of the avian fluvirus as far as Africa this year.

${ }^{\alpha}$ The impact in Africa will be dramatically different from the impact in Europe," says Hagemeijer. Rural communities around the lakes of the Rift Valley region depend heavilyon poultry to survive, and live in close contact with both domestic and migratory birds.

The FAO's chief veterinary officer, Joseph Domenech, said on 19 October that African countries should be given international assistance to help them look out for the virus and control any outbreaks. He warned that if the virus becomes endemic in Africa, the chances of it mutating to spread between humans, potentially triggering apandemic, will increase.

But the most immediate threat is the economic loss that will result if large numbers of poultry succumb to the disease or have to be culled. "Losing poultry would have a devastating effect on livelihoods in the area," says Lea Borkenhagen, sustainable-living development manager at the charity Oxfam, UK. "Women in particular would be affected, as poultry

\section{Ornithologists on the front line}

Geese take off from a pond in rural France at the start of Jacques Perrin's 2001 film Winged Migration, which follows the birds until they returnthenextspring. Perrin tracked dozens of bird species across every continent, capturing the huge scale of the migration phenomenon.

Migratory birds are now being tracked aga in, but this time because they are suspected of spreading the avian flu vinus. The role of wild birds in this has been controversial, and ornithologists are quick to point out that, in many cases, the direction and timing of fluspread is at odds with what is known about migratory routes. But after recent outbreaks of the $\mathrm{H} 5 \mathrm{~N} 1$ strainin wild birds in Romania, Turkey and Greece, experts have little doubt that it was carried by birds migrating from Siberia, Kazakhstanand Mongolia, where $\mathrm{H} 5 \mathrm{~N} 1$ outbreaks occurred earlier in the year.

The worry now is that birds heading from the north to their southern wintering grounds will vastly expand the range of the $\mathrm{H} 5 \mathrm{~N} 1$ virus - and that their return in spring will bring a new wave of virus to the north. Governments desperately want to know where and when further outbreaks are likely, so ornithologists have been thrust into the spotlight. Wetland sites across the world have become the new front line against bird flu.

Ornithologists depict themain migration corridors as 'flyways', drawn on maps with breeding grounds at one end, overwintering sites at the other, and the area that birds fly over to get from one to the other (see map). Flyways bundle together the routes of dozens of species, estimated from ringing studies, and give a general picture of where infected birds might go. Many birds fly from Siberia to Europe, but the main route is towards southwest Asia and east Africa, says Jan Veen, an expert on Siberian migration routes at Wetlands International. Two other large flyways connect Siberia to the Indian subcontinent, and another goes to the Black Sea and north and east Africa. The recent European outbreaks seem to be along this last flyway, says Veen, suggesting that countries along this route are atrisk.

Flyways can also help to show where different species cross paths 


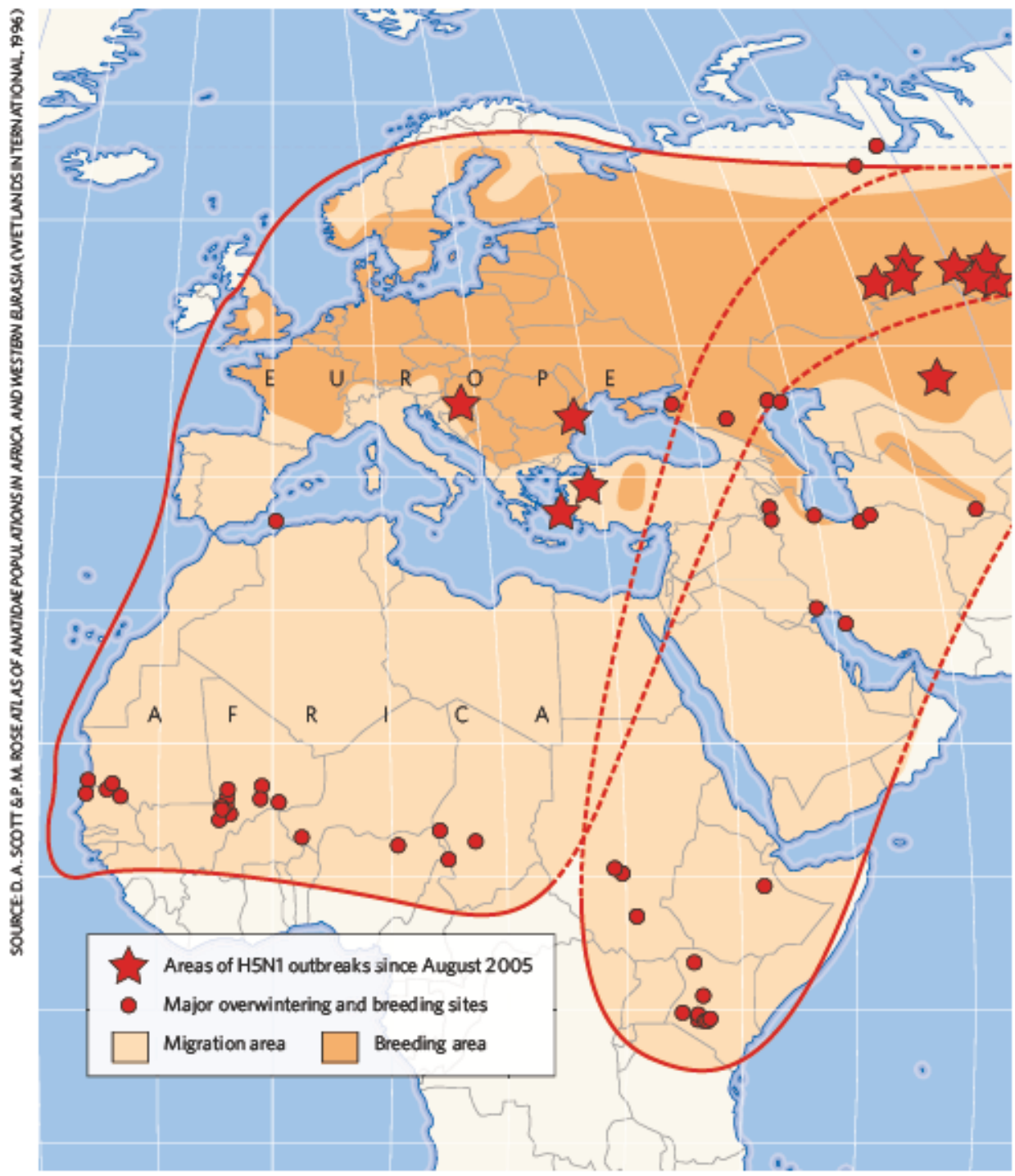

Mass migration: red outlines show flyways of the Garganey duck, a species at high risk of spreading the H5N1 virus. The birds breed in the north in summer (dark orange) and then fly south for the winter. represent the only assets they can possess."

Tadelle Dessie, a poultry researcher at the International Livestock Research Institute in Addis Ababa, Ethiopia, agrees. Earlier this year he travelled to Vietnam where more than 40 people have been killed by $\mathrm{H} 5 \mathrm{~N} 1$, and spent time with experts working to contain the virus and develop systems to spot it early. ${ }^{\text {T}}$ The situation in Africa could be worse," he warns.

There is concern that, so far, not enough is being done to look out for bird flu in the region. "We need to raise awareness of the risks," says Hagemeijer. "Experts know about it, but there is no wider coordination." He is currently travelling in Africa as part of an effort by Wetlands International to establish a network of people monitoring water birds for signs of the disease.

Few countries in the area have systems in place to test for H5N1. And efforts to control outbreaks would be hampered by the difficult terrain in remote communities around the region's lakes, as well as by the low level of education across the region. "Our estimate for the Rift Valley is that literacy rates are between $10 \%$ and $40 \%$, with women at the lower end," says Borkenhagen. ${ }^{\alpha}$ That's much lower than in countries such as Vietnam, so it will be hard for people to take on the kind of information that will have to be given."

Dessie says his attempts to get the Ethiopian government to acknowledge the problem have so far been unsuccessful, but that he hopes the FAO's warning will lead to action.

In response to Domenech's statement, Kenya, Sudan and Tanzania have all imposed restrictions on poultry imports, and Tanzanian livestock officials say they are teaching people in wetland areas to keep poultry away from wild birds. East African nations will meet next month in Rwanda to develop a regional strategy to handle the threat of bird flu. and birds in one flyway might infect those on another. Of particular interest are the flyways of ducks, geese and swans, as these come into closer contact with humans than do waders and cranes. They are also frequent carriers of flu, with up to $20 \%$ of birds infected.

But for accurate risk assessments, researchers need to look at the routes of individual species and even populations, and to take into account a host of other factors such as bird virology. Until now thishas not been a well-funded area, and data are severely lacking for instance, vast databases of ringing data covering the pastcentury could provide more precise information, but there has been little money to analyse them, says Jacquie Clarke, head of the ringing unit at the British Trust for Omithology.

A more high-tech way to track migrationusessatellitemonitoring of birds fitted with global positioning system (GPS) antennas. On the hub between the Eurasian and North American flyways, birds can be tracked in real time tojust a few metres, says Dirk Derksen, chief of the wetlands and terrestrial ecology branch at the Alaska Science Center.

Until recently, the weight of GPS antennas restricted their use to large birds such as swans, but miniaturization now allows smaller birds to be tagged. But the technique remains very expensive. The Alaska Science Center is also working with the US Air Force on another technique: getting detailed information on the movements of bird flocks from radar data.

But as scientists rushto understand the role of migratory birds in spreading avian flu, those watching birds flying from Europe to Africa fear that the process is already under way. "Lake Victoria receives huge numbers of migratory birdsfrom eastern Europe and Siberia," says Achilles Byaruhanga, executive officer of Nature Uganda, with some 2 million white-winged tems expected at the Lutembe Bay marshland sanctuary alone.

Byaruhanga is monitoring migration for conservation purposes - this year, he will also be looking out for dead birds. But Uganda, he adds, has no system in place to monitor birds for $\mathrm{H} 5 \mathrm{~N}$. Declan Butler 